Jour. Japan. Assoc. Min. Pet. Econ. Geol., Vol. 47, May, 1962

\title{
TEXTURES AND STRUCTURES OF THE GOLD-COPPER ORES OF THE CHINKUASHIH MINE, TAIWAN
}

\author{
C. K. HUANG \\ Department of Geology, National Taiwan University
}

\begin{abstract}
Various textures and structures indicative of cavity-filling and replacement of the Chinkuashih gold-copper ores are described and interpreted.

They are in general characterized by the formation under the conditions of low temperatures and shallow depths. However, there is no evidence for the hypogene minerals deposited as colloids even in the interesting botryoidal and reniform ores.

It is worthy of note that inter-mineral movement has occurred after deposition of enargite and luzonite and before that of alunite.
\end{abstract}

\section{INTRODUCTION}

The Chinkuashih gold-copper deposits emplacing in Miocene sediments and dacites, along sub-parallel N-S fault zones as irregular lenses or pipes are of epithermal fissure-filling and replacement origin (Huang, 1955). The structural and lithologic controls of the ore localization and three alteration envelopes around the deposits are marked. The ore minerals are pyrite, enargite, luzonite, and native gold, accompanied by such gangues as quartz, barite, alunite, wurtzite, and kaolinitic clay. The study of crystal morphology and surface patterns revealed that pyrite shows the trend of variation in habit from cube through pyritohedron to octahedron according to the grade of mineralization from low to high (Huang, 1955; 1960b). It has also been clarified that both vertical and lateral zonings are present in the deposits of the area (Huang, 1955; 1960a). The active exploration carried out at the Chinkuashih mine since 1955 has obtained some success in finding new ore bodies and the extensions of known deposits with substantial tonnages of ores (Huang, 1960c). 
This paper deals with the textures and structures of the ores characteristic of the deposits, the critical interpretation of which would contribute to a sound diagnosis of the origin and is attempted here.

\section{Cavity-filling Textures and Structures}

The Chinkuashih ores have been found mainly in the following openings: (1) sheeted fissures and breccia cavities; (2) beddingplanes and joints; (3) shear fractures; (4) solution cavities of calcareous sandstones and dacites. With the exception of (4) formed by silicification, the first three directly or indirectly have a genetic relation to the N-S normal faulting (Huang, 1955; Wang, 1955). These openings appear to have been not only the important channelways of mineralizing solutions but also the loci of ore deposition. Following are main textures and structures indicative of cavity-filling.

Crustification of a few successive bands of such minerals as pyrite, enargite, luzonite, quartz, alunite, and barite is the most common structure and particularly developed in the sheeted veins of the lenticular deposits (Huang, 1955). An example of this structure with massive luzonite and tabular crystals of barite on a silicified and argillized dacite is shown in Fig. 1, Nos. 1 3 exhibit crustified banding of enargite and pyrite filled by alunite along the bands, partly grading to cockade or rosette texture (Schwartz, 1951). The spheroidal surfaces of the pyrite layers are somewhat similar to colloform texture.

The solution cavities in oval shape of the Astriclypeus or calcareous sandstones by silicification are often lined with beautiful drusy crystals of quartz, pyrite, enargite, and barite in the order of deposition (Fig. 1, No.4). It is also common that the phenocrystic negative crystals of silicified dacites are lined with quartz with its long axes perpendicular to the walls and filled by pyrite of octahedral form. (Fig. 3, No.2). In this case, impregnation of pyrite in the silicified matrix is usually recognizable, and both filling and replacement appear to have been guided by irregular fissures of microscopic dimensions, as evidenced by occasional occurrence of 
segmented veinlets of quartz and pyrite in the groundmass (Bastin, 1950).

The sub-parallel shear fissures in silicified shales are frequently filled by quartz, partly showing comb texture (Fig.1, No. 5). Fig. 1 No. 6 indicates a pyrite veinlet with minor euhedral quartz traversing a silicified sandstone breccia, which is also impregnated by pyrite. Fillings of these small fractures, while seldom showing crustification probably due to quick filling, occasionally show a segmented character as stated above.

Cockade structure is also quite common in the Chinkuashih ores and especially developed in the pipe-shaped deposits that are localized in highly brecciated zones (Huang, 1955). Some ores show a combination of crustification and cockade structure. A ring ore of coarse crystals of enargite and pyrite forming a part of banded structure is exhibited in Fig. 2 No. 1. Fig. 2, No. 2. shows silic fied sandstone breccias enclosed by successive crusts of octahedral pyriteand prismatic enargite. As in this example, many of rock breccias appear not to be in contact with other fragments or with the walls of the cavity, presumably due to a moderate amount of dislodgement by the crystallization force of the enclosing new minerals under low pressures (Emmons, 1940). The vugs in the banded or cockade ores are often filled by kaolinitic clay, the last mineral to deposit.

An interesting botryoidal ore from the 3rd Changjen deposit consists of radiating, prismatic crystals of enargite with spherul tic pyrite as the center, which are successively covered by a thin laye of pyrite, sporadic tabular crystals of barite, and massive luzonite (Fig. 9). Another interesting ring ore is represented by a reniform aggregate of pyrite from the $500 \mathrm{~m}$ ore pipe (Fig. 2 No. 4). Under the microscope, pyrite is interbanded with alunite with speckles of enargite, and both pyrite and alunite crystals show radial texture with their elongations nearly perpendicular to the walls of the bands (Fig. 2, No. 5). These ores with rotund outline seem to have been deposited in the crystalline rather than the colloidal state under low temperatures and pressures, since there is no textural evidence indicative of colloidal deposition (Bastin, 1950).

It is worthy of note that in the $500 \mathrm{~m}$ ore body the crusts of 
enargite, luzonite, and pyrite on silicified sandstone or dacite fragments are often brecciated and recemented by alunite, showing the occurrence of inter-mineral fracturing (Fig. 2, No.6). In the alunite veins, the fine-grained crystals are crusted with the coarse ones showing undulatory extinction. The minute skeletal cubic crystals of pyrite occasionally found on the drusy alunite represent the last sulfide to form (Huang, 1960b). Network structure exhibited by alunite veinlets traversing the irregular cracks of an underlying enargite band is occasionally observable in the Tsushihshan South ore pipe which is localized in the same brecciated zone as the $500 \mathrm{~m}$ deposit (Fig. 3, No. 1). As the result of the minor fracturing before deposition of alunite mentioned above, this structure is found in the intermediate layer between enargite and alunite bands that crusted on the breccias of silic fied sandy shales.

Besides, massize structure of fissure-fillings by enargite and pyrite is locally present particularly in the lower parts of the deposits

\section{Replacement Textures and Structures}

Replacement is also an important process in the mineralization of the Chinkuashih deposits. It is in general associated with cavityfilling and developed along various kinds of openings.

Pseudomorphic replacement textures are well revealed in the altered wall rocks (Huang, 1955). In silicified dacites all the phenocrysts except quartz have been dissolved and the groundmass altered to an aggregate of fine-grained quartz, resulting in hard porous rocks with the original porphyritic texture. Subsequent filling of the phenocrystic negative crystals and replacement of the groundmass by pyrite and enargite are rather common in the ores (Fig. 3, No.2). In argillized or chloritized and carbonatized dacites preservation of the porphryitic texture leaving the quartz phenocrysts intact is also noted. Fig. 3, No. 3 illustrates a dacite suffered from silicic and argillic alteration, in which the kaolinitized phenocrysts have further been replaced by aggregates of alunite. This mineral is characteristic of intense alteration near the deposits and evidently represents a considerable activity of sulfuric acid solutions, thus 
fixing the potassium as sulfate rather than as sericite or other potassium-bearing silicates. Selective pyritization of mafic minerals such as hornblende and biotite is occasionally observable in the silicified and alunitized dacites, the iron of these minerals apparently entering into the pyrite (Huang, 1955, Pl. 5, Fig. 1). The preservation of mineral cleavage after replacement is often distinct in the mafic phenocrysts of chloritized and carbonatized dacites (Fig. 3, No.4). Textures characteristic of sedimentary rocks are also not uncommon both in the altered wall rocks and in the ores. Two excellent illustrations of preservation of bedding are shown in Figs. 3 Nos. 5 and 6, in which replacement structures of silicified laminated shales and sandstones by pyrite, luzonite, and enargite taking advantage of the bedding planes are well revealed.

Incrustation-pseudomorphs of quartz after barite and luzonite after enargite are less frequently found in the ores (Huang, 1955). It appears that the removal of the original mineral has gone on simultaneously with the incrustation of another mineral, showing the unstableness of the former under the conditions the latter deposited. However, this is not replacement, since no guest takes the place of the host.

In contrast to the pseudomorphic replacements just described that have mostly been guided by structural or textural features of the host such as fractures, bedding planes, mineral contacts, cleavages, etc., there may be automorphic replacements in which diffuse penetration of the replacing solutions plays a more important role (Bastin, 1950). Octahedral crystals of pyrite probably developed by this kind of replacement are often seen in silicified shales and the silicified matrix of dacites (Huang, 1955, Pl. 5, Fig. 4).

It is to be noted that neither cavity-filling nor replacement by hypogene minerals of colloidal origin have been recognized in the Chinkuashih deposits, though various textures and structures of the ores stated above are mostly indicative of deposition under the conditions of low temperatures and shallow depths.

\section{CONCLUSION}

The textures and structures of the Chinkuashih gold-copper 
Figure 1. Photomicrographs of cavity-filling textures and structures.

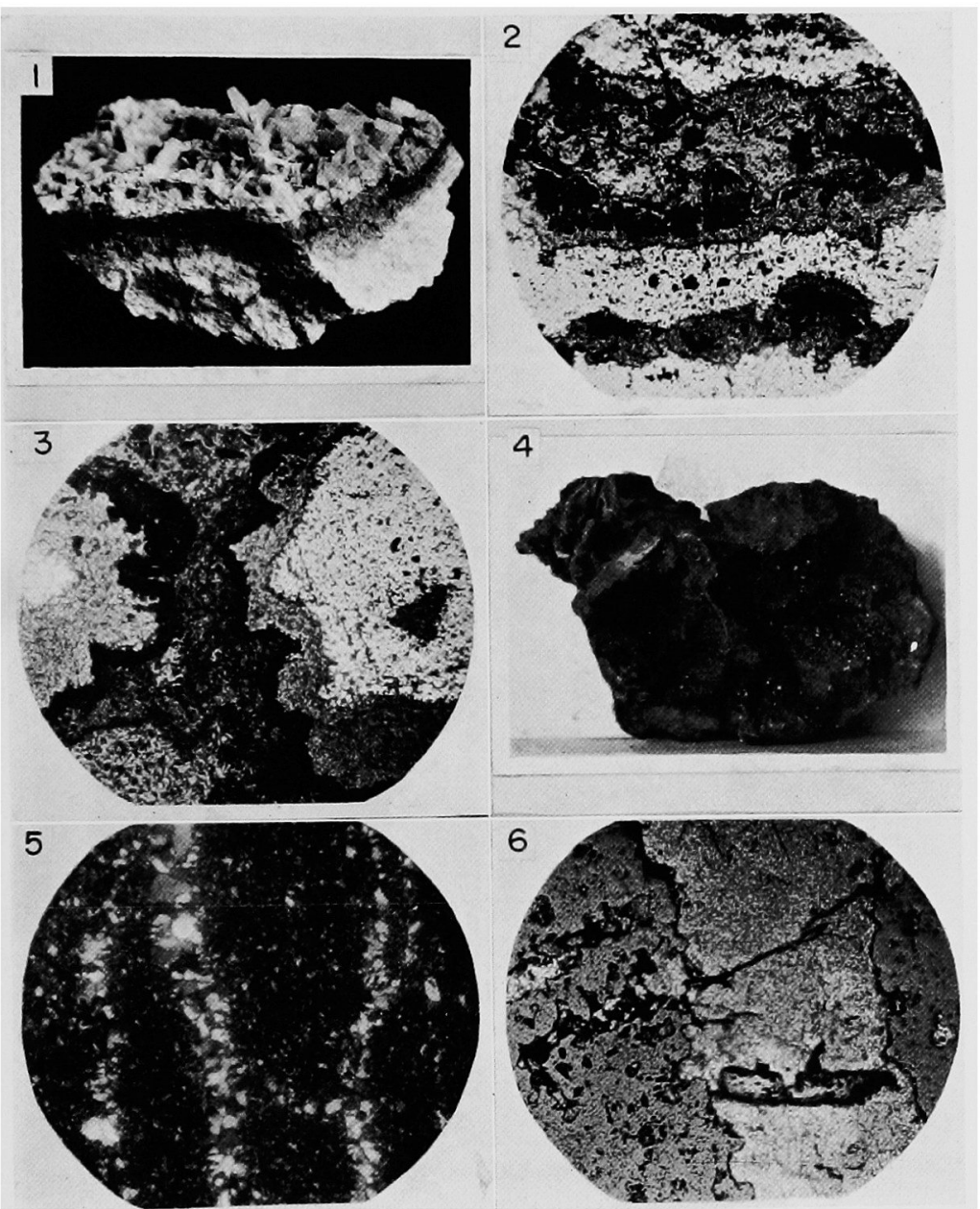

1. Crustification of luzonite (black) and barite (white) on dacite. Penshan ore body. $\times 1 / 2$.

2. Banded texture of enargite (white) and pyrite (gray). Dark gray: alunite. $500 \mathrm{~m}$ ore body. Polished section, without nicol, $\times 25$.

3. Cockade or rosette texture in No 2. Polished section, without nicol, $\times 25$.

4. Drusy crystals of quartz, pyrite, enargite and barite. $\times 1 / 4$.

5. Comb texture of quartz. Niufu ore body. Thin section, crossed nicols, $\times 40$.

6. A pyrite veinlet traversing a silicified sandstone breccia. 3rd Changjen ore body. 6th adit. Polished section, without nicol, $\times 25$. 
Figure 2. Photomicrographs of cavity-filling textures and structures.
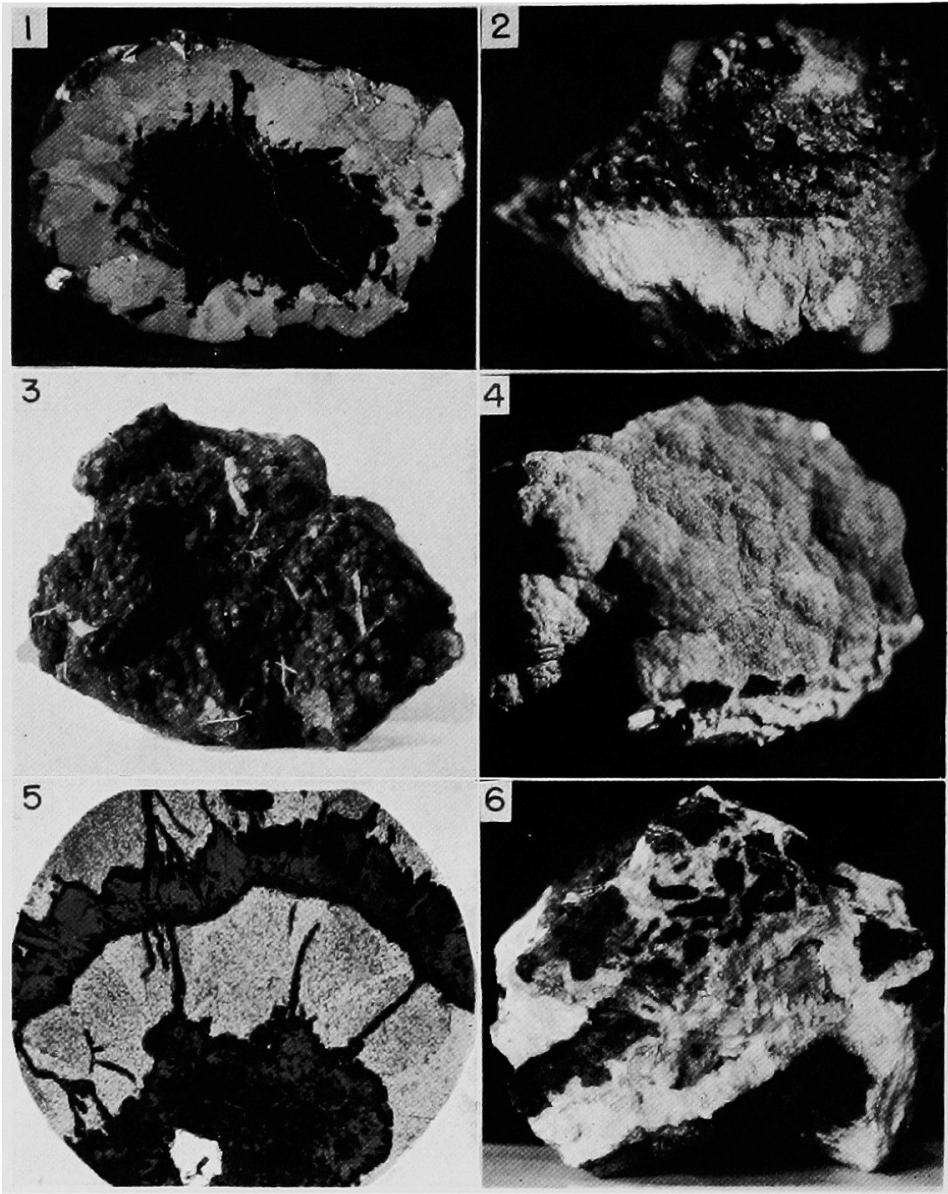

1. Cockade structure shown by enargite (black) and pyrite (gray). Penshan ore body. $\times 1$.

2. Ring structure exhibited by pyrite and enargite enclosing silicified sandstone breccias. Penshan ore body. $\times 1$.

3. A botryoidal ore. 3rd Changjen ore body. $\times 1 / 3$.

4. A reniform aggregate of pyrite. $500 \mathrm{~m}$ ore body. $\times 1$.

5. Cockade texture exhibited by the same specimen as shown in No. 4. gray: pyrite dark, gray : alunite, white : enargite. Polished section, without nicol, $\times 25$.

6. Brecciated structure of the ore minerals (black). Note the recementation by alunite (white). $500 \mathrm{~m}$ ore body. $\times 2 / 5$. 
Figure 3. Photomicrographo of cavity filling replacement textures and structures.

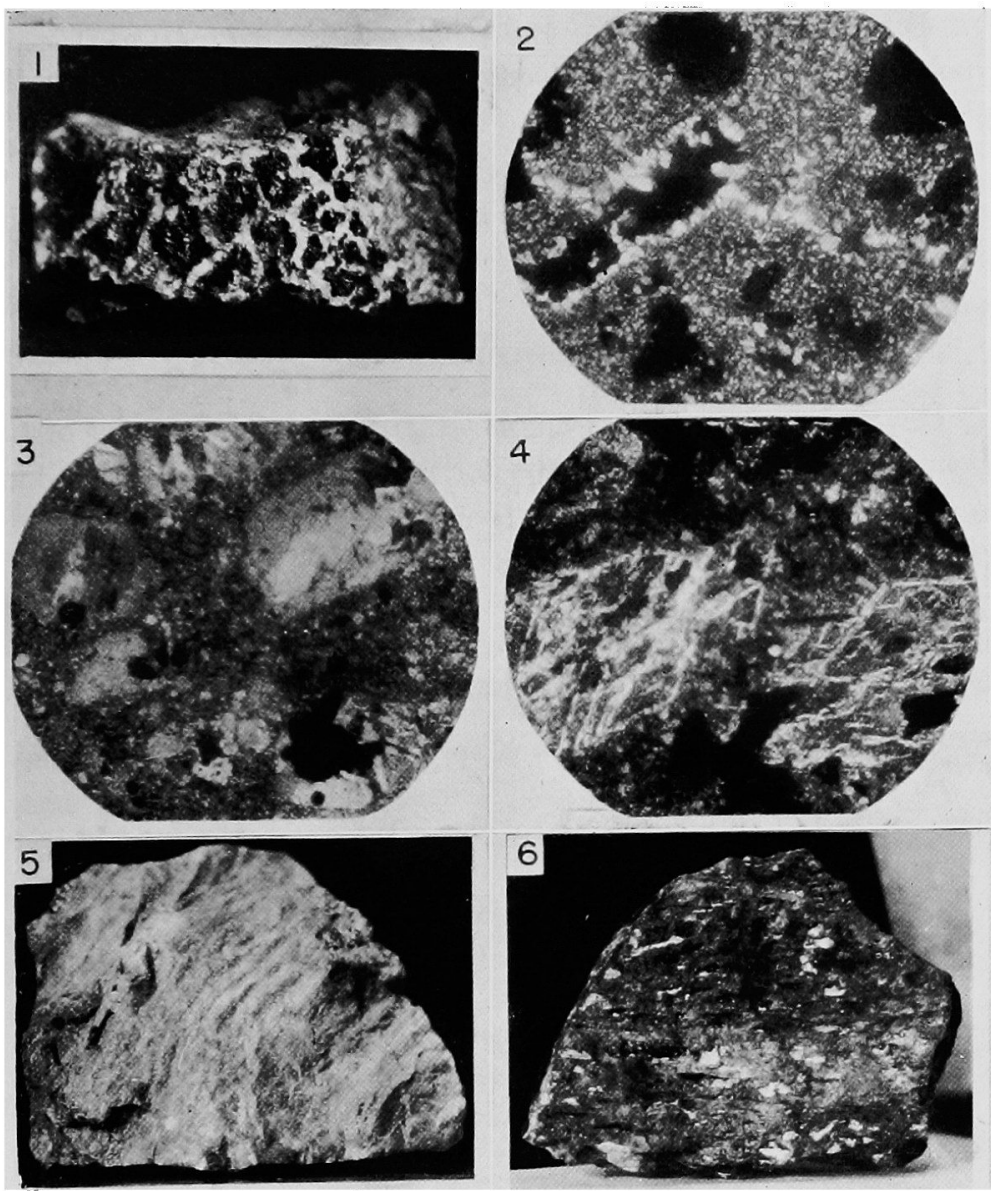

1. Network structure exhibited by alunite (white) and enargite (black). Tsushihshan South ore body. $\times 3 / 5$.

2. The original porphyritic texture of a silicified dacite. Penshan ore body. Thin section, crossed nicols, $\times 40$.

3. Partial replacement of the kaolinitized phenocrysts in a dacite by aggregates of alunite. Black: pyrite. Penshan ore body. Thin section, crossed nicols, $\times 40$.

4. Hornblende in a chloritized and carbonatized dacite. Penshan ore body. Thin section, crossed nicols, $\times 40$.

5. Silicified laminated shales and sandstones replaced by pyrite. Lucky ore body. $\times 3 / 5$.

6. Replacement structure of silicified laminated shales and sandstones by pyrite, luzonite, and enargite. A number of small vugs along the bedding are filled by enargite and alunite. Tsushihshanoe body. $\times 1 / 3$. 
ores are as a whole characterized by the formation under the conditions of low temperatures and shallow depths. However, no hypogene minerals of colloidal origin have been found even in the botryoidal and reniform ores.

Inter-mineral movement has taken place after deposition of enargite and luzonite and before that of alunite, as evidenced by brecciation of the ores.

\section{ACKNOWLEDGMENTS}

The writer expresses his appreciation to Mr. W. F. Chen of the Taiwan Metal Mining Corporation for his kind assistance in taking the photographs. This work has been made possible by the research fund from the National Council on Science Development, the Republic of China.

\section{REFERENCES}

Bastin, E.S. (1950) Interpretation of ore textures. Geol. Soc. $1 \mathrm{~m}$. Mem., 45, 14-55.

Emmons, W. H., (1940) Principles of economic geology. McGraw-Hill Book Co., New York, 73.

Huang, C.K. (1955) Gold-copper deposits of the Chinkuashih mine, Taiwan, with special reference to the mineralogy. Acta Geologica Tairexnica, no. $7,1-20$.

_- (1960a) Gold deposits of the Wutanshan area, Taiwan, and their relation to the Chinkuashih deposits. Acta Geologica Taimanica, no. $8,13-26$.

- - - (1960b) Surface structures of pyrite, enargite, barite, and alunite from the Chinkuashih mine, Taiwan. Acta Geologica Taiwanica, no. $8,27-36$.

- - - - (1960c) Results of prospecting by Mineral Survey Team at the Chinkuashih mine during 1957-60. Mineral Survey Team Ann. Rept. 1959-60, 1-17.

Schwartz, G. M. (1951) Classification and definition of textures and mineral structures in ores. Econ. Geol., 46, 578-591.

Wang, Y. (1955) Fracture patterns in Chinkuashih area, Taipeihsien, Taiwan. Acta Geologica, Taiwanica, no. 7, 21-34. 